\title{
Germany and the Muslim World
}

\author{
Christoph Marcinkowski*
}

\section{Germany, the 'Friend of the Muslims': Some Bright (and not so Bright) Spots}

The relations between the world of Islam and Germany (or what was then the Holy Roman Empire) date back far into the Middle Ages and were particularly intense during the times of the Crusades. However, Muslims came to Germany in larger numbers as part of the diplomatic, military and economic relations between Germany and the Ottoman Empire in the eighteenth century. German diplomats and travellers, in turn, visited the Ottoman lands as well as Safavid Persia from the fifteenth and sixteenth centuries, respectively.

In Muslim public opinion, Germany appears to have been always seen as the 'friend of the Muslims', a kind of 'exception' compared with other Western colonial powers which controlled large chunks of the Muslim homeland. Germany - so it was thought - had no colonial ambitions in the Dār al-Islām. Germany's last emperor, William II (r. 1888-1918), during his famous 1898 speech in Damascus, declared himself the 'eternal friend' of the (then) 300 million Muslims in the world. In a symbolic act, he even financed in that city for the upgrading of the tomb of Saladin, the Muslim war hero who fought during the Crusades against King Richard Cœur-de-Lion of England - England, the main opponent of the Kaiser's expansionist agenda. That the Kaiser used at other occasions also to advocate a 'Place in the Sun' (by which he was not so much referring to the expansion of the German tourism sector but the acquisition of colonies for the Reich) might perhaps only disturb the minds of somewhat more sensitive individuals. At that time, the Reich had no difficulties in allying itself with 'pan-Islamist' Sultan 'Abd al-Hamīd II (r. 1876-1909), who is revered even today by fundamentalist and certain right-wing strata, especially in Turkey. As it is well known, Germany took part significantly in the reform of the armed forces of the ailing Ottoman Empire. Consequently, Germany fought side-by-side with its Ottoman ally during the Great War, enabling the Ottomans - under the command of the Imperial German field-marshal Wilhelm Leopold Colmar Freiherr von der Goltz ('Goltz Pasha') - even to destroy the British invaders in December 1915 during their first attack on Iraq at the Battle of al-Kūt.

* Christoph Marcinkowski is Principal Research Fellow at IAIS Malaysia. At the time of writing, his latest book, Schiiten in Deutschland. Dialogbereitschaft und-verständnis von muslimischen Minderheitsorganisationen, was in preparation. 
Some 23,000 British and Indian soldiers died in the attempts to retake al-Kūt probably the worst loss of life for the British away from the European theatre.

During the subsequent darkest period of Germany's history, the 'Third Reich' even used widespread Muslim sentiments against increased Jewish immigration into Palestine, and some units of Hitler's brutal Waffen-SS consisted exclusively of Muslims of a variety of ethnic backgrounds. In part, Serbian atrocities against the Bosnians in the 1990s wars that followed the destruction of unified and multicultural Yugoslavia can be traced back as a revanche to the slaughters of ethnic Serbs carried out by Muslim Bosnian SS units during World War II.

Particularly disturbing, to my mind, was also the role played by Muhammad Amīn al-Ḥusaynī during his tenure as Grand Mufti of Jerusalem, when Heinrich Wolff, the then German Consul-General in Palestine, sent a telegram to Berlin reporting al-Husaynī’s belief that Palestinian Muslims were supposedly enthusiastic about the new regime and looked forward to the spread of Fascism throughout the region. As a matter of fact, al-Husaynī visited both Mussolini and Hitler (greeting the latter repeatedly with raised right arm, the infamous 'German salute'). Germany's involvement with the Muslim world in the past had thus a variety of facets...

\section{Germany's Present Stand in the Muslim World: Opportunities and Challenges}

However, Germany's association with the Muslim world has also featured some rather bright spots. Several prominent figures of German-language intellectual life are known for their positive attitude to Islam. Johann Wolfgang von Goethe (1749-1832), for instance, Germany's most famous literary artist, was writing a verse drama on the life of Muhammad at his death. His work West-östlicher Diwan (1819) shows sympathies with the world of Islam and its intellectual and literary achievements. Friedrich Rückert (1788-1866), the professor of Oriental languages, translated the Qur'ān as well as Persian poetry into German. This list could be continued...

Moreover, in the world of scholarship Germany has been able to paint a less sensational picture of Islam and the Muslim world that often tends to be somewhat more balanced and accurate - although the motives behind this may often have been driven by self-interest. Academic periodicals such as Der Islam, established as far back as 1912, contribute to these efforts. To this day, it continues to be one of the country's leading academic journals in Islamic studies. Moreover, German scholars, such as the late Harvard professor Annemarie Schimmel (1922-2003), a leading expert on Sufism and Islamic spirituality, are still respected also in the Muslim world. 
In the field of internal politics, Germany's current CDU/CSU-FDP federal coalition government is going to continue the Deutsche Islam Konferenz (DIK) project initiated by the painstaking efforts of former federal interior minister Dr Wolfgang Schäuble, which is aiming at producing somewhat more meaningful results in the dialogue between the German state and the country's Muslim organisations. In the light of several million Muslims residing and working peacefully in Germany, the recent announcement of the government that the DIK is going to continue are to be highly appreciated.

In the arena of international politics, German federal governments made up by Social-Democrat/Liberal coalitions had been able to engage Yasser Arafat's PLO in a dialogue, and the achievement of a ceasefire at the end of the 1980-88 war between Iraq and Iran is seen by political analysts as mainly the result of 'good contacts' of Bonn with Tehran, as well as Baghdad. In line with Germany's past as the major initiator of World War II, Social-Liberal federal governments repeatedly rejected an active participation of Bundeswehr units in UN peace-keeping operations or other active military ventures of the United Nations. It had been argued by some although not by this writer - that such uses of the German armed forces outside the NATO territory would not be authorised by the Grundgesetz, the German Federal Constitution. Germany's usually good relations with the Muslim world in the past may have played a part in this decision.

At the same time, Germany has also 'special responsibilities' as a result of its World War II genocide of the Jewish people - rightly so, in the view of this writer. Germany's 'unique position', however, could also well enable it to have a restraining influence on Israel as well as certain countries that are often portrayed as 'rogue states', among them being Iran. Germany, with 4,500 soldiers and policemen, the third-largest contributor of troops to the UN-backed mission in Afghanistan, has so far also played a positive part in that country in terms of building up and training local security forces and in helping the country in numerous development projects, especially in the East, where German forces are predominantly stationed.

\section{Perspectives}

Today - within the context of the West's rather strained relationship with the Islamic world at large - Germany could play an even more constructive role by investigating carefully its foreign policy $v i s-\grave{a}$-vis the Muslim world, weighing its political and economic interests and the long-term consequences. On the other hand, Germany cannot stand aside when it is asked by the international community or a Muslim country like Afghanistan for assistance. However, Germany's internal security, too, could be affected negatively as it would now also become a convenient target for 
terrorists. Whether such a scenario would be in the long-term interests of Germany - economic and otherwise - remains to be seen.

Germany's military engagements abroad should be backed up - even more than it is already - by credible economic and development aid as well as training for the security forces of Afghanistan, where Germany is already present - based on a UN-mandate and on its NATO obligations of mutual defence.

Germany's new Federal Minister of Defence, Karl-Theodor Freiherr von und zu Guttenberg, is thus not to be envied in his new position which he took over only in October 2009 from his predecessor Franz Josef Jung. As a matter of fact, zu Guttenberg recently addressed only a fact, when he referred to the situation in Afghanistan as 'war' - rather than a mere 'peace-securing operation'. As Germany has no economic or strategic interests whatsoever in Afghanistan, the sacrifice - at the time of writing (November 2009) - of 39 German lives should deserve somewhat more gratitude - at home as well as abroad. 